\title{
From Student's Experience: Does E-learning Course Structure Influenced by learner's Prior Experience, Background Knowledge, Autonomy, and Dialogue
}

\author{
Hassan Abuhassna \\ Faculty of Social Sciences \& Humanities, School of Education, Universiti Teknologi Malaysia, 81310, UTM \\ Skudai, Johor, Malaysia \\ ORCID: 0000-0002-5774-3652
}

Abdelsalam H. Busalim

Irish Institute of Digital Business, DCU Business School, Dublin City University, Dublin, Ireland ORCID: 0000-0001-5826-8593

Babakura Mamman

Faculty of Education, University of Maiduguri, P.M.B. 1069, Maiduguri, Borno State Nigeria

ORCID: 0000-0001-9055-1006

Noraffandy Yahaya

Faculty of Social Sciences \& Humanities, School of Education, Universiti Teknologi Malaysia, 81310, UTM

Skudai, Johor, Malaysia

ORCID: 0000-0002-7952-5461

Megat Aman Zahiri Megat Zakaria

Faculty of Social Sciences \& Humanities, School of Education, Universiti Teknologi Malaysia, 81310, UTM

Skudai, Johor, Malaysia

ORCID: 0000-0001-8223-8124

Qusay Al-Maatouk

School of Digital, Technologies and Arts, Staffordshire University, Stoke on Trent, United Kingdom

ORCID: 0000-0003-4654-9464

Fareed Awae

Faculty of Social Sciences \& Humanities, School of Education, Universiti Teknologi Malaysia, 81310, UTM

Skudai, Johor, Malaysia

ORCID: 0000-0001-9121-5020

Received: 28 May 2021

Accepted: 11 Oct 2021

\begin{abstract}
Background: E-learning is increasingly becoming a preference in higher education institutions worldwide; this is intended to assist educational institutions in achieving objectives to meet the proportion of individuals with their educational opportunities. Nevertheless, instructors and students frequently have concerns with their capacity to succeed in E-learning environments.

Objectives: This study aimed to presents common eLearning challenges in regard to e-learning courses structure and its relations to various factors, for instance; students' autonomy, prior knowledge and experience, students- students dialogue, and students- instructor dialogue, and proposes solutions to these challenges based on the transactional distance theory. Moreover, this study presents evidence from
\end{abstract}


Malaysian higher institutions based on theoretical models for e-learning course structure and its relations to the factors mentioned above.

Methods: Data have been collected from 680 university learners all over Malaysia. Data were then examined using exploratory factor analysis, confirmatory factor analysis, and structural equation modelling employing Smart PLS 3.0 software.

Results and conclusion: Research findings indicated that e-learning course structure was affected by all dimensions of overall path analysis findings: student autonomy, students background, student-instructor dialogue, and student-student dialogue. However, the e-learning course structure showed insignificant with students' prior experience.

Implications: Implications for universities are discussed accordingly. Such findings provide vital support to the integrative association among collaborative control (CC) and transactional distance theory (TDT) regarding e-learning environments experience, which might support universities administrators in the higher education industry to implement, plan and evaluate online learning platforms applications in their institutions.

Keywords: e-learning courses structure, e-learning student background, e-learning student autonomy, elearning dialogue

\section{INTRODUCTION}

E-learning offers access to higher education institutions to a wide variety of students. Including face-to-face learners on campus, students who are working; thus, looking for opportunities to pursue their degree or post-degree through their working experience to be able to switch their career path, individuals who are looking for a flexible time scheduling possibility, those who choose not to take part in face-to-face environments, and finally those who have abnormal circumstances, for instance, nowadays COVID-19 outbreak that affected all worldwide educational systems. E-learning platforms offer a chance to learn whenever and wherever they prefer to, regardless of any limitations in their time scheduling. Education, in general, is the process of obtaining skills and knowledge via learning or by other methods despite any particular purposes. Moreover, e-learning offers a real chance for learners with various lifestyles to make it possible to study without restrictions in a safe and secure atmosphere (Bradford et al., 2007; Chawdhry et al., 2011; Heirdsfield et al., 2011). Learners will also be able to accelerate managing and organizing the content of their course (Heirdsfield et al., 2011; Squillante, 2014; Wilson, 2007), in addition to assignments submitting through e-learning (Wilson, 2007), offering continuous feedback to learners (Bradford et al., 2007), grading the students, and monitoring groups (Chawdhry et al., 2011; Wilson, 2007), in addition to evaluating students through the whole process (Heirdsfield et al., 2011).

Furthermore, e-learning offers rooms for sharing information that could be beneficial for learners to obtain a more comprehensive view of the syllabus. eLearning collaboration tools within can improve learners' social collaboration and assist them in communicating with their classmates and discovering individuals with comparable interests in such a secure and educated atmosphere. Nevertheless, the reality of e-learning implementation has included some obstacles and difficulties, despite what elearning has as additional functionalities, for instance, marks grading, chat discussions, along with e-mail, in addition to what is has of social media constructions like wikis and blogs, yet, it has not maintained e-learning to preserve pace with such quick technology change, precisely with interaction and collaboration types which exists for the time being (Stern \& Willits, 2011).

There are still some doubts regarding the collaboration tools in e-learning to be as effective as other accessible, collaborative applications. This tendency and manner of education have altered throughout the years. An overwhelming majority of learners are expected to use laptops, tabs, notebooks, smartphones, and numerous other instruments to obtain knowledge concerning academic and non-academic matters. Increasingly, the conventional way of education has decreased over the years; thus, learners are becoming increasingly keen to learn employing technology that is easier and quicker. Nowadays, education should not be restricted to the traditional face-to-face environments only; therefore, physical presence is not a 
requirement anymore for education to occur (Zhang \& Nunamaker, 2003). Technology in education has enhanced the education process; education is becoming substantial for modern learning. Technologies need to be utilized as an educational tool; thus, concerns must be provided on how learners acquire the objectives to implement advanced technologies (Jonassen et al., 1999). Learning systems that are guided by technology are easy to implement among learners due to the convenience it provides; in addition, the process of this modern way of learning is not restricted to instructors or facilitators; moreover, the physical distance is no longer a challenge (Raab et al., 2002). Computers in education are being utilized as a tool through the elearning process (Ghavifekr \& Rosdy, 2015). Individuals can use various tools such as smartphones and laptops, giving them more freedom to access e-learning at their own pace. Thus, this gives them a sense of self-regulation (autonomy) towards education as a whole (Abuhassna et al., 2020). In particular, for college learners, e-learning may be an excellent tool for developing knowledge and keeping them posted wherever they are. Many university learners nowadays are utilizing a wide-ranging version of e-learning tools and education methods (Adams et al. 2018; Chopra et al. 2019). However, to what extent e-learning structure courses are efficient for both instructors and learners? Many learners can be easily distracted and confused if they lack background knowledge on how to use e-learning the correct way. The e-learning process should go through a communication process, whether between themselves and their classmates and their course instructor. Thus, it is necessary to examine the degree to which e-learning meets university students' needs and characteristics (Cidral et al., 2018; Selvaraj, 2019).

Accordingly, this study presents evidence from Malaysian higher educational institutions regarding e-learning course structure. Thus, it presents common elearning challenges in regards to e-learning courses structure and its relations to various factors, for instance; students' autonomy, prior knowledge and experience, students- students dialogue, and students- instructor dialogue, and proposes solutions to these challenges based on the transactional distance theory (Moore, 1972, 2013) and collaborative control (White, 2003). The proposed model of this study helps both instructors and students overcome obstacles to success, while parallel training based on the same standards prepares teachers to accelerate practical elearning experiences. The gap of this study relies on the fact that e-learning course structure has not been investigated in previous research with relation to these factors presented in this study. These five factors have been investigated to recognize the model's elements and the e-learning course structure and are being shared to illustrate the model's effectiveness. Moreover, this study differs from other studies due to the fact that it has contributed to the scientific literature by identifying five e-learning course structure factors that must be considered when designing e-learning environments in Malaysian educational institutions. Additionally, the findings reveal a positive relationship amongst overall e-learning course structure and all independent variables of the study, regardless of the student's prior experience. The approach was employed with online classed through e-learning platforms. Moreover, the proposed model and its components may be employed in any discipline and analyzed to help determine its efficacy in helping students in e-learning platforms.

\section{Problem Statement}

E-learning provides noteworthy chances for students to quickly access new education levels that were out of reach before. Moreover, it plays a key role for educational institutions who want to highlight the obstacles related to the resources needed to increase their physical structure to increase student enrolment, thus benefiting from outreach beyond their campus. Accordingly, higher educational institutions' stakeholders' and administrators' first concerns are the effectiveness of this delivery method. Negative feedback has thrived on several institutions ' campuses, whether from instructors themselves or students, regarding online learning and the physical separation and learning experience. On the other hand, the growing evidence to the contrary and growing participation and interest is noteworthy to be examined furthermore. Accordingly, concerns involve e-learning course structure and its relations to students' autonomy during e-learning courses, their prior knowledge and experience towards e-learning environments, and the communication process during e-learning environments, for instance, students- students dialogue and students- instructor dialogue. Every one of these components needs to be addressed and examined. The current study focuses on e-learning course structure and the approaches that situate both instructors with their learners to have a practical e-learning experience. 


\section{Theoretical Background and Hypothesis Development}

All efforts must be utilized throughout all learning environments to guarantee that both instructors and learners achieve their goals and purposes. Such a process includes the course structure itself, the course design and steps, the skills needed from both instructors and learners, and finally, monitoring and managing the course. Online learning platforms such as e-learning provides their factors set related to the success of the course, for instance, a lesser extent of structured experience for students since there are few or no faceto-face meetings through the online process; a learning guideline regarding the delivery of the course, and what technologies are to be implemented, and that is a crucial concern for both instructors and learners to the same extent. Highlighting the methods and strategies for discussing and sharing the course materials which in face-to-face environments could easily be provided, on the other hand, in online learning environments, there must be a theoretical method that needs to be adopted and expanded to grantee such success in online learning environments. Thus, both instructors and students must be trained and skilled in this modern teaching and learning method. Although learner's success in every learning environment, more specifically in online learning environments where this success relies on several aspects, not all of these aspects are controllable by the instructor or the facilitator; thus, a lot could be done to alleviate and anticipate obstacles during online learning sessions. Likewise, facilitators and instructors who have consistent knowledge of online learning methods and strategies and the capability and skills to implement them will have the opportunity to provide a great online learning session to achieve the session's objectives and make their learners enjoy such an experience.

This study was constructed based on two main theories, first, the theory of transactional distance (TDT) (Moore, 1972, 2013), in the distance education field that presents understandings into the association amongst crucial factors in online learning environments, for instance; course structure, instructor, students, along with, the nature of physical distance that is caused by the separation among the instructor and his $\backslash$ her learners. Second, The collaborative control (CC) concept of White (2003). That is commonly employed to distance learning environments. It clarifies the myth that online learning environments are synonymous with independence in education; thus, it proposes collaboration and communication strategies in online learning environments. Accordingly, these two concepts may be employed in the course structure and the instructor's training to increase opportunities in association with online learning environments and helps both instructors and learners develop the required abilities and skills in online learning environments.

\section{Transactional Distance Theory (TDT)}

Firstly, Transactional Distance Theory (TDT) is discussed by (Moore, 1972, 2013), which has three elements: learners' autonomy, course structure, dialogue between instructors and their students, and dialogue among students themselves. The course structure is supplied by course assignments, quizzes, deadlines, course materials, and the content of the course, which are fixed based on the course that has been made accessible to learners. The course structure is a crucial pedagogical tool resource that offers students consistency in sequencing and organizing educational materials, content, assignments, and quizzes. Commonly, courses are structured in such a way that every session contains the same parts and several pages in the same course have an identical format, which is comparable to the textbook or the content of the course, which assists students in understanding what to anticipate as they progress in their course. The course curriculum is part of the structure as well, as it directs learners over the course requirements and provides necessary information about the grading and procedures of the course. Moreover, Course structure could also be made available by communicating with learners to support and guide students through the course. This type of communication mentioned has been referred to as Dialogue in TDT, which contains any interaction or exchange through the course.

This may be between the students and their classmates or between students and their instructor or facilitator. This contains course characteristics such as discussion forums, assignments peer review, the course announcements, assignments feedback, learners' queries, e-mail, long live meetings. Hence, dialogue gives more socialization, primarily through collaboration and interaction through the course. Teacher dialogue may motivate students, assist them in identifying their weaknesses and strengths and help improve. 
Structure and dialogue amount in any course influences learner's autonomy or (their self-regulated learning), which is defined as the opportunity to choose described by elements of self-regulated learning. Lesser structure and dialogue levels create a greater autonomy level among students. Some students can function correctly with low structure and dialogue levels, while others need more support and assistance. Autonomous learners can determine their learning goals thus, move towards achieving these goals. Autonomous learners have both emotional independence and instrumental independence (Moore, 1972, 2013). In other terms, they can succeed through the course along with little support and require little motivation. It is expected that students could become more autonomous throughout the course time in their online course because they realize what is expected from them and obtain the confidence they need to succeed. Teachers can accelerate these confidence-building measures. The autonomy, dialogue, and structure goals support learning results, thus avoiding learner's fail.

\section{Collaborative Control (CC)}

Secondly, collaborative control concept of White (2003). This concept offers greater insight into the social environment characteristic of self-regulated education and the dialogue component of TDT. Instead of imagining online learning as an autonomous activity, the concept of collaborative control admits that learners could learn from their classmates and thus support one another and the teacher that could encourage student's success and communications. Asking for assistance or help is a positive practice for so long as students are not excessively reliant on others. It is necessary for them to understand whenever they need assistance, recognize the best help resources, and assess the help effectiveness that is received (Andrade \& Evans, 2013). Collaborative control (CC) occurs when the instructor and students cooperate to complete a task, thus enhancing the learning results successfully. Instructors should be aware of collaboration goals to create greater autonomy levels among learners to make the right decisions and, thus, have the required confidence to be successful. Nevertheless, one of the standard online learning critiques is the social communication lack among students; therefore, instructors and course designers must always be conscious of the possibilities to offer this particular aspect in online learning environments.

\section{Hypothesis Development}

The hypothesis development of this study was constructed based on the combination of the different aspects of the theories mentioned above. Courses online require students to participate in forethought (background and experience) led to the instruction of the first hypothesis, H1: Students' background knowledge has a positive influence on course structure. Then students' performance during the online course led to the instruction of the second hypothesis, $\mathrm{H} 2$ : Student's prior experience has a positive influence on course structure. Opportunities for dialogue (students and instructor communications) led to the third hypothesis, H3: Students- instructor dialogue positively influences course structure. Furthermore, collaborative control between students among themselves, which led to the fourth hypothesis, H4: students-students dialogue has a positive influence on course structure, all of which are offered by the instructor; and that use these features to support students increasingly develop better autonomy, which led to the final hypothesis of the study, H5: students autonomy has a positive influence on course structure, (capability to manage factors that are affecting the learning process), and targeted knowledge and skills (the content of the course and other related outcomes) as they apply what they are learning, reflect on their learning, and set goals. This demonstrates how these two theories work parallel to improve this study's dependent variable, course structure based. This proposed model explains how the theories of TDT, and the concept of CC can guide elearning course structure, thus, help both instructors, students, and decision-makers in the online learning industry.

\section{E-learning Environments}

E-learning environments are increasingly becoming a prevalent educational tool as internet consumers grow each passing day (Goyal, 2012). There are countless factors to measure e-learning effectiveness: personalization, organization, user-friendliness, responsiveness, ease of use, reliability, security, and stability (Tseng et al., 2011). Analyzing e-learning effectiveness may depend on various factors; in his study, Gamage 
et al. (2014) mentioned the top five factors: collaboration, pedagogy, networking, motivation, and interactivity. E-learning effectiveness via video depends on the interactivity provision of the course (Zhang et al., 2006). Additional research findings discovered that the effectiveness of e-learning environments is highly associated with e-learning quality, the instruction of multimedia, and learning activities interactivity (Liaw, 2008). A developed model on affecting e-learning factors by Wang (2003) that he proposed includes four main factors: personalization of the participants, the course, the community of learning, and the content learner interface. This study proposes five additional factors that affect e-learning course structure: learners' prior experience, learners' background knowledge, autonomy, the dialogue (students - students), and the dialogue (students - instructors).

Moreover, more factors have been examined by Islam et al. (2010). These variables are online learning technology familiarity, learning achievement and outcome, learner's satisfaction, and reaction, which significantly influence the e-learning effectiveness. E-learning quality has been investigated by Tseng et al. (2011), who recommended that the attractiveness of the software to students is the most crucial measure of the effectiveness of e-learning.

Additionally, decreasing the time and the instructor's responsiveness to a reply to the student's query could enhance the quality of the experience leading to the e-learning effectiveness. Salter et al. (2014) carried out a study to verify the effectiveness of e-learning has discovered that effectively e-learning impact increases the students' knowledge. However, this study has not revealed whether e-learning can effectively enhance students' professional practice or skills. Furthermore, Noesgaard and Orngreen (2015) has found that it is not easy to guarantee the effectiveness of e-learning to enhance the teaching and learning process. In contrast, the course instructor cannot employ several strategies and methods of teaching as required. Elearning environments could be cost and time effective; besides, they could be effortlessly utilized to fulfil the learning requirements. In addition, e-learning environments offer more freedom to learners to be more entertained and interactive (Goyal, 2012).

Johnson et al. (2000) claimed that e-learning environments could be more effective than face-to-face environments for providing learners with updated knowledge to accomplish learning objectives. Similarly, Rosenberg et al. (2003) claimed that e-learning environments are at least as effective as face-to-face environments. E-learning significantly increases the access to learning anywhere and anytime, improves the quality of teaching and learning, and reduces the learning cost (Gilbert et al., 2007). E-learning environments are considered a potential replacement for face-to-face environments (Welsh et al., 2003). E-learning environments are comparatively less expensive than face-to-face environments; in addition, it is a studentcantered method that enables learners to obtain skills in various ways, for instance, video, text, image. (Strother, 2002). a survey has been conducted on e-learning environments by Unwin (2008) which revealed that most participants commented that e-learning is crucial and valuable to meet their needs. E-learning environments enable students to control the course content, fix time scheduling, determine learning pace, and select the most suitable media to meet their learning objects and manage the course materials (Jethro et al., 2012).

\section{LITERATURE REVIEW}

This part of the study has been structured based on the hypothesis of the study.

\section{Course Structure}

The structure is the ability for the learning to be customized and tailored to the learner (Moore, 1973). Moore (1997) described a structure that "states the flexibility or inflexibility of the program's learning aims, instructional strategies, and assessment techniques. It also defines the point to which an educational program can facilitate or be reactive to each student's requirements." (p. 30). A learning environment that offers students flexibility and personalization allows the student to feel more connected to the learning environment (Moore, 1997). Flexible or low-structured learning environments reduce the transactional distance within a learning environment (Lee \& Rha, 2009). Learning activity or environment's structure can 
also be described in terms of its formality, individualization, and various learning activities (Huang et al., 2015). Formality is described as clear and rigid adherence to a present learning structure (Kearsley \& Lynch, 1996). Formal learning environment structures have present and clear-cut sequences of class content, learning activities, assignments, and assessments (Lee \& Rha, 2009). In highly formalized learning environments, an educator's assessment of learning objectives is made from the beginning of the learning process (Lee \& Rha, 2009). It stands in contrast to the educational environment established by John Dewey.

Dewey argued for a learning environment where students could be free to develop their meaning for their experiences and an individualized environment (Dewey, 1997). This idea was echoed by Kearlsey and Lynch (1996), who pointed out that a flexible- or loosely structured course allowed for greater student understanding. A flexibly structured class focuses on the individual students and allows individuals to share with an educator the ownership and creation of course objectives, activities, and assessment (Huang et al., 2015; Kearsley \& Lynch, 1996; Moore, 2013). This allows students to personalize the education setting with class content, learning activities, assessment of learning goals, the pace of the learning, and learning settings (Christensen, 2015). It is essential to point out that the presence of a flexible or low-structured learning environment reduces the transactional distance; it is not always the most optimal design for a learning environment (Benson \& Samarawickrema, 2009). In some learning objectives and systems that require a present content and understanding, participating in a highly structured formal learning environment ensures uniformity among students (Benson \& Samarawickrema, 2009). It allows students to meet learning objectives linearly and shorten the learning objectives process (Christensen, 2015). A flexible learning environment may not be the opposite of a highly formal educational setting. However, an educational setting can maintain a degree of formality while focusing on the individual needs and backgrounds of the students or population (Huang et al., 2015).

\section{Student's Background Knowledge}

Students' background factor in online learning environments plays an important role. As suggested in prior studies, there are employment issues in online learning environments, such as learners' readiness, course structure, facilities provided by the educational institute, learners' acceptance to online learning, and instructors' qualifications. Nevertheless, learners' usage of online learning environments is increasing, aiming to globalize their audiences due to its eventual accessibility, flexibility, and exceptional functionality (Azhari \& Ming, 2015). There have been persistent concerns about the quality of online learning environments in comparison with face-to-face environments. Prior studies (Panyajamorn et al., 2018; Paechter \& Maier, 2010) found that students still prefer face-to-face environments due to a lack of background knowledge regarding using e-learning, interaction reasons, and social relations in face-to-face environments. Furthermore, Lau and Shaikh (2012) revealed that Malaysian students' computer skills and internet efficacy, in addition to their demographics like financial income, level of the study, background, and gender, led to a significant variance in their online learning readiness.

Furthermore, Abuhassna and Yahaya (2018) claimed that technology in education has made education easier. It plays a crucial role in delivering online learning sessions that as effective as traditional classes despite the psychological separation of instructors and their learners. Online learning environments going through the applications of less complexity in the teaching and learning process, achieving individuals desires that are do not have the opportunity to enroll in face-to-face classes. Additionally, online learning Platforms are the most appropriate ways for autonomous learners (Abuhassna et al., 2020; Abuhassna \& Yahaya, 2018; Paechter \& Maier, 2010; Panyajamorn et al., 2018). Students' background knowledge towards e-learning platforms is yet another dominant element in implementing e-learning successfully (Adams et al., 2018; Rasouli et al., 2016). Students' background knowledge could possibly be examined by evaluating students' knowledge (Adams et al., 2018; George et al., 2014), technological expertise (George et al., 2014; Rasouli et al., 2016), availability of technology (Anene et al., 2014; Rasouli et al., 2016; Adams et al., 2018), self-directed education (Kaur, 2014), internet and computer effectiveness (Kumar, 2017), as well as the attitude (George et al., 2014; Kumar, 2017) through e-learning settings. Whilst the familiarity of e-learning, yet there is a shortage of studies and well understanding on Students' background knowledge towards e-learning platforms (Adams et al., 2018). 


\section{Students Prior Experience}

Learners' prior experience in online learning provides numerous advantages to online learners in improving learners' skills, particularly for isolated students (Jaques \& Salmon, 2007; Lau \& Shaikh, 2012; Salmon, 2011, 2014). Nevertheless, of learner's acknowledgment of the benefits of supporting their learning by applying technology in education, complications could occur through their technical abilities restrictions besides prior experiences about employing the software and its functionality. Over the years, it was demonstrated that the lack of feedback and experience in online meetings might often develop a frustration source among instructors and their learners, which may cause uncomplicated tasks, for example, uploading a or submitting an assignment, setting for a quiz or an exam, watching a video, besides other simple responsibilities to be increasingly difficult for them if they do not have the required skills and knowledge and no prior experience. Additionally, when they fill out the assessments, such as presentations online, a relatively limited ability to interact traditionally and rely on a non-verbal signal in conjunction with the audience's body language could be a depressing factor. On the other hand, the implication of being in a situation to take part with classmates in online sessions that are occasionally nonvisual, for example, teleconference set-up is an increasingly important skill in modern sessions, therefore affirming the importance of intensive, clear, concise, communications skills (Salmon, 2011, 2014).

\section{Dialogue}

Dialogue in the present research refers to communication, collaboration, the interaction between learners and their instructors, and learners among themselves to improve learners' understanding and engagement with the course content. Per (Shearer, 2010) interaction must be constructive because it is based on the concepts and work from others, such as assisting others in teaching and learning. (Moore, 1972) declared that students also need to understand the significance of learning communication as an essential part of teaching and learning. Similarly, Benson and Samarawickrema (2009) investigated instructors' preparatory learners, Falloon (2011) examined digital tools' role to help to assist students' communications and interactions in a case study conducted in New Zealand. Likewise, Mathieson (2012) studied the dialogue role it plays in online learning sessions; she developed a survey that analyzed learners' perception of audio-visual feedback in classes that use digital tools, such as screencasting. Moore (2007) examines autonomous students looking for factors that do not affect dialogue and structure to improve their learning experience. (Abuhassna et al., 2020; Abuhassna \& Yahaya, 2018; Furnborough, 2012) revealed that learners' cooperation with their classmates impacts their reaction concerning their collaboration with their classmates. Moreover, To examine and refine TDT, Rabinovich (2009) developed a questionnaire to examine TDT in higher education institutions; the questionnaires were sent to 235 learners, who were enrolled in asynchronous web-based graduate sessions employing TDT and Collaborations, the synchronous learning setting was defined as a place where "live on-campus courses are taken instantaneously to together in-class learners on campus besides remote learners virtually who join through e-learning environments" which permits learners to communicate with both their classmates and their instructor instantaneously (Rabinovich, 2009). Furthermore, Falloon (2011), Kassandrinou et al. (2014), Mathieson (2012), and Vasala and Andreadou (2010) stated that teachers play an essential role as communication and interaction supporters since they are responsible for assisting, reassuring, and encouraging interaction and communication between learners.

\section{Student Autonomy}

Autonomous learners in this research are referring to their motivation and independence in learning. Students' autonomy in learning exposes their requirements and expectations. Thus, autonomy in online learning environments is of extraordinary importance since the ability to choose is offered in online education, which empowers students in learning autonomy (Massimo, 2014). Furthermore, in this regard, the relationship between learners' autonomy and specific parts of the learning process is highly considered. Madjar et al. (2013) has concluded that a learners' autonomy-supportive settings offer these students acceptance of online learning, which leads to more educational accomplishments. This is why autonomy is required in online environments for either learner's development or better accomplishment in university 


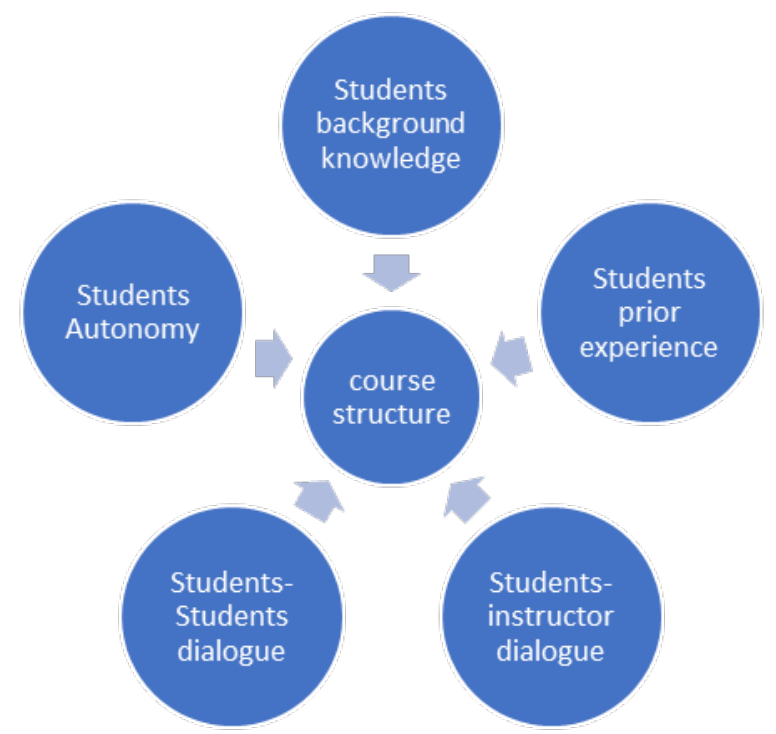

Figure 1. Conceptual framework

settings. Researchers have also suggested that autonomy strengthens outcomes in aims and goals, guiding instructors' methods primarily to achieve goals.

Consequently, autonomy learning environments have to be designed with affective aspects consideration as well. Nevertheless, Stroet et al. (2013) effectively studied 71 experimental research about the effects of autonomy-supportive education on learner's motivation and found a clear positive association. Students will not reach the same autonomy level without studying students' autonomy insights, reflecting on their educational experiences, sharing these experiences and reflections with their classmates, and understanding the factors that influence these procedures (Jacobs et al., 2016).

\section{RESEARCH METHOD}

\section{Study Population}

According to ministry of higher education in Malaysia (MOHE) statistics there are 291.53 thousand male students and 415.02 thousand female students as a total enrollment from both undergraduate and postgraduate students in Malaysian public universities (MOHE, 2021). The non-purposing sample selected from the population of both undergraduates and postgraduate students in the second semester 2020 - 2021.

\section{Study Sample}

A total of 700 surveys have been distributed online through google forms; excluding 20 questionnaires have been excluded as they were incomplete surveys, 680 were analysed employing SmartPLS. Thus, the total number of valid questionnaires was 680 following this exclusion. Such an exclusion step is being recommended by Hair et al. (2012). Furthermore, Venkatesh et al. (2012) indicated that this method is vital to be carried out as outliers could be a reason for incorrect results. About the participants' demographic particulars: 249 (34.3\%) were males, and 385 (56.7\%) were females. $358(52.6 \%)$ were in the age range of 18 to 20 years old, 169 (24.9\%) were in the age range of 21 to 24 years old, and $37(5.4 \%)$ were in the age range of 25 to 29 years old. Regarding the level of study: 401 (59.4\%) were from level $1.190(28.1 \%)$ were from level 2, 31 (4.6\%) were from level 3, 21 (4.6\%) were from level 4, and $32(4.7 \%)$ were from level 5 and above.

\section{Sample Calculation}

The size of sample was calculated with consultation of statistician and by using the G-power-sample size software [confidence limit $=0.05$, expected proportion or prevalence $(p)=0.78 \%$ ]. Strata Calculation by using 
the formula: $\mathrm{nh}=(\mathrm{Nh} / \mathrm{N}) \mathrm{X}$. Where, $\mathrm{N}=$ Size of total population, $\mathrm{nh}=$ sample size for the stratum (ward), $\mathrm{Nh}=$ population size for the stratum, and $\mathrm{n}=$ Size of total sample.

\section{Participants and Pilot Study}

The survey in this study was conducted on a total of 680 university students who were selected randomly out of the population of public universities all over Malaysia. To examine the research instrumentations' validity and reliability, this study conducted a pilot study on around 20 percent of students from the population. The pilot study survey follows similar procedures of a real data collection. However, in the pilot study only a small population was identified for their participation.

\section{Survey Instrument}

The current study questionnaire has been designed to fit the hypothesis of the study. Therefore, it has been structured based on both theories, which have been used in current research. This questionnaire consists of two parts; the first part is to measure student background knowledge and stunts prior experience towards e-learning. The second part aims to measure students- students Dialogue; instructor- students dialogue, students' autonomy, course structure based on TDT theory variables. Items of the questionnaire have been adapted to guarantee the validity of the content. The first section included the participants' demographic particulars involving educational level, gender, and age. The second section contains 31 items adapted from prior studies: student background knowledge (S.B.K.) consists of five items. Secondly, student experience (S.S.) consists of five items adapted from Akaslan and Law (2011). Thirdly, student collaborations (Dialogue) consist of five items as well that were adapted from Bolliger and Inan (2012). Fourthly, student autonomy (S.A.) consists of five adapted items (Barnard et al., 2009; Pintrich et al., 1991). Finally, the course structure (C.S.) consists of six adapted items (Abuhassna et al., 2020). Moreover, the survey has been distributed to the students after experiencing e-learning courses for semester 2, 2019-2020, all over Malaysian higher education institutions.

\section{Variability and Reliability}

To determine the content validity and reliability index. The content validity was carried out by two experts in the Educational Technology field in Universiti Teknologi Malaysia (UTM). The experts were chosen based on their research interests and expertise in Educational Technology. As they were requested to identify and evaluate whether the questions agreed with the extent and scope of items to which these items represent the concept of the research problem. In addition to evaluating that the instrument can be used and statistically valid, moreover, the questionnaire was planned suitably to provide relations and examined variables.

\section{The Structural Equation Model}

The Structural Equation Model was used in the present research to test the hypothesis of this study, and the methodology used is Partially Least Square (P.L.S.). To analyze the obtained data, Smart P.L.S. software version 3.0 was used. This study included two types of evaluations: (a) evaluation of the measurement model and (b) evaluation of the structural model. The evaluation of the measurement model explores the relationship between constructs/latent variables and their measures to determine discriminant or convergent validity (Chin, 2010). However, with particular regard to Hetrotrait-Monotrait (HTMT) and Fornell-Larcker, the emphasis of the evaluation in this study depends on discriminant validity.

\section{RESULTS}

\section{Measurement Model Assessment}

The measuring model assessment was conducted by examining the reliability and the convergent and discriminant validity of the constructs and their associated items (Hair et al., 2016). The reliability of the measurement model was carried out by testing two metrics: the Cronbach alphas and composite reliability 
Table 1. Measurement model assessment

\begin{tabular}{|c|c|c|c|c|c|}
\hline Construct Name & Items & Outer loadings & Cronbach's Alpha & $\mathrm{CR}$ & AVE \\
\hline \multirow[t]{5}{*}{ Students background knowledge } & SBK1 & 0.853 & 0.861 & 0.9 & 0.643 \\
\hline & SBK2 & 0.877 & & & \\
\hline & SBK3 & 0.751 & & & \\
\hline & SBK4 & 0.715 & & & \\
\hline & SBK5 & 0.802 & & & \\
\hline \multirow[t]{5}{*}{ Students prior experience } & SPE1 & 0.718 & 0.822 & 0.875 & 0.583 \\
\hline & SPE2 & 0.748 & & & \\
\hline & SPE3 & 0.793 & & & \\
\hline & SPE4 & 0.79 & & & \\
\hline & SPE5 & 0.768 & & & \\
\hline \multirow[t]{5}{*}{ Students- instructor dialogue } & SID1 & 0.81 & 0.887 & 0.918 & 0.692 \\
\hline & SID2 & 0.871 & & & \\
\hline & SID3 & 0.883 & & & \\
\hline & SID4 & 0.87 & & & \\
\hline & SID5 & 0.713 & & & \\
\hline \multirow[t]{5}{*}{ Students-Student's dialogue } & SSD1 & 0.806 & 0.908 & 0.932 & 0.732 \\
\hline & SSD2 & 0.831 & & & \\
\hline & SSD3 & 0.882 & & & \\
\hline & SSD4 & 0.892 & & & \\
\hline & SSD5 & 0.863 & & & \\
\hline \multirow[t]{5}{*}{ Students Autonomy } & SA1 & 0.845 & 0.863 & 0.902 & 0.649 \\
\hline & SA2 & 0.875 & & & \\
\hline & SA3 & 0.775 & & & \\
\hline & SA4 & 0.83 & & & \\
\hline & SA5 & 0.689 & & & \\
\hline \multirow[t]{5}{*}{ Course structure } & CS1 & 0.844 & 0.857 & 0.899 & 0.644 \\
\hline & CS2 & 0.815 & & & \\
\hline & CS3 & 0.86 & & & \\
\hline & CS4 & 0.849 & & & \\
\hline & CS6 & 0.62 & & & \\
\hline
\end{tabular}

(CR). The results, as shown in Table 1, reveal that all the values of the Cronbach alpha and CR exceeded the required threshold of 0.7 and 0.5 , which indicate that the measurement model of the current study is reliable. The convergent validity refers "to the extent to which a measure correlates positively with alternative measures of the same construct" (Hair et al., 2016, p. 112). In this study, convergent validity was assessed using the items' outer loadings and the Average Variance Extracted (AVE). As shown in Table 1, the outer loadings and AVE values have exceeded the recommended values of 0.7 and 0.5 (Hair et al., 2019), However, one item (CS5) was removed from the model due to low outer loading value (<0.6) (Hair Jr et al., 2016). Overall, the results of the measurement model assessment demonstrates that the reliability and convergent validity was established. 


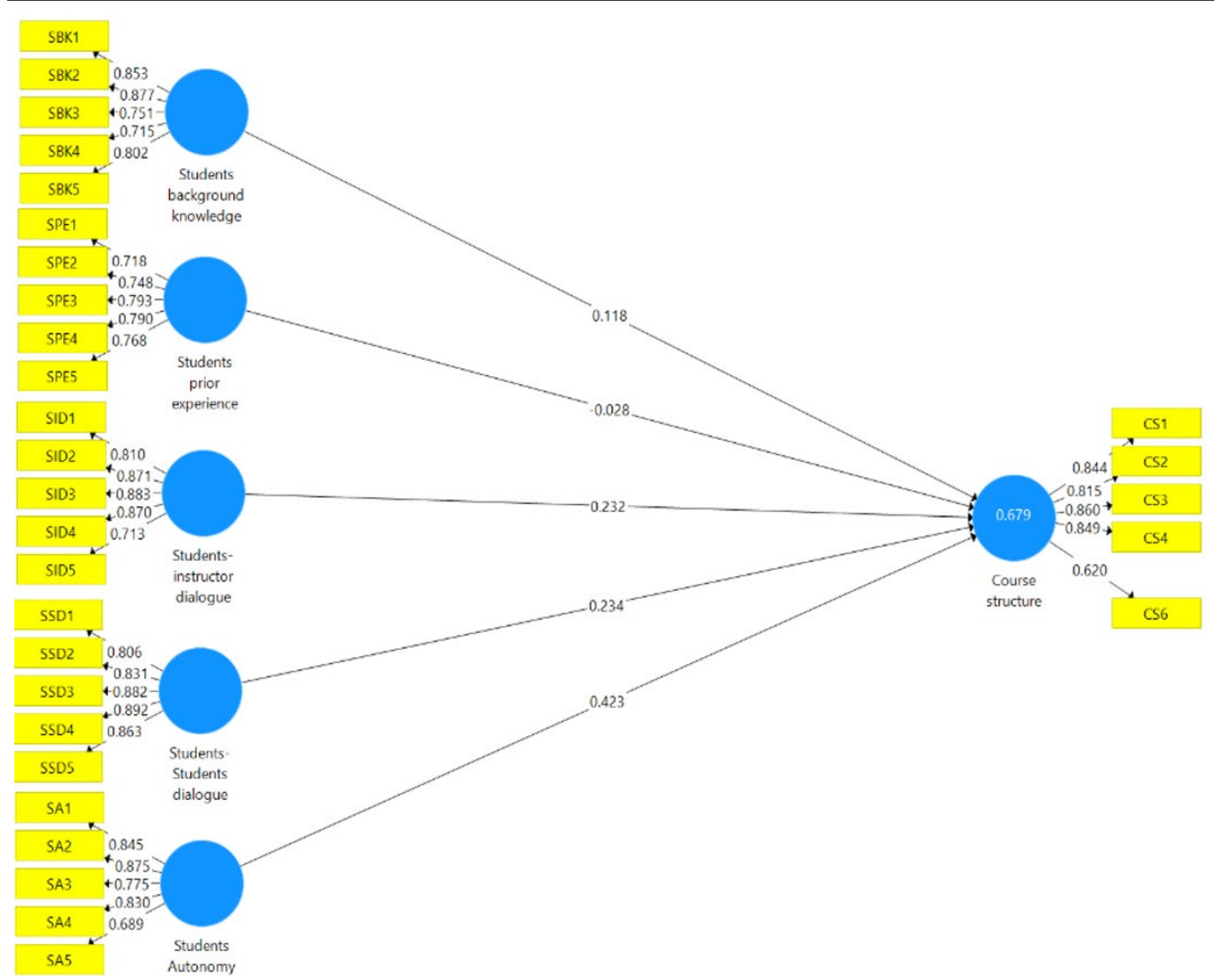

Figure 2. Measurement model

\section{Discriminant Validity}

Discriminant validity refers to the extent to which one construct is distinct from other constructs by empirical standards (Hairs et al., 2016). Discriminant validity was carried out by testing two metrics: Fornell-Larker Criterion and hetero-trait-mono-trait ratio (HTMT). The Fornell-Larker Criterion compares the square root of the AVE value of a specific construct with other constructs correlations in the model (Fornell \& Larcker, 1981; Hair et al., 2017; Leong et al., 2015). Table 2 shows the square root of the AVE of each construct was greater than its highest correlation with any other construct. This indicates that there are no discriminate validity issues in the model. Furthermore, (HTMT) was tested as a new criterion for assessing discriminant validity. HTMT is defined as "the average of the correlation indicators across constructs measuring different phenomena, relative to the average of the correlations of indicators within the same construct" (Henseler et al., 2015, p. 121). HTMT was used in this study as an estimate to demonstrate what is the true correlation between two constructs would be if they are both perfectly reliable (Hairs et al., 2016). If the HTMT value between two constructs is close to 1 , it means that the model lacks discriminant validity (Hair et al., 2016; Henseler et al., 2015). According to Henseler et al. (2015), the threshold value of HTMT is 0.90 for the structural models that include conceptually similar constructs. The result, as shown in Table $\mathbf{3}$ shows that the HTMT value of each construct is below the threshold value of 0.90 , which confirms that the discriminant validity is established. 
Table 2. Fornell-Larcker criterion

\begin{tabular}{|c|c|c|c|c|c|c|}
\hline & $\begin{array}{c}\text { Course } \\
\text { structure }\end{array}$ & $\begin{array}{l}\text { Students } \\
\text { Autonomy }\end{array}$ & $\begin{array}{c}\text { Students } \\
\text { background } \\
\text { knowledge }\end{array}$ & $\begin{array}{c}\text { Students prior } \\
\text { experience }\end{array}$ & $\begin{array}{l}\text { Students- } \\
\text { instructor } \\
\text { dialogue }\end{array}$ & $\begin{array}{c}\text { Students- } \\
\text { Student's } \\
\text { dialogue }\end{array}$ \\
\hline Course structure & 0.803 & & & & & \\
\hline Students Autonomy & 0.754 & 0.806 & & & & \\
\hline Students background knowledge & 0.569 & 0.605 & 0.802 & & & \\
\hline Students prior experience & 0.494 & 0.581 & 0.651 & 0.764 & & \\
\hline Students- instructor dialogue & 0.679 & 0.628 & 0.527 & 0.461 & 0.832 & \\
\hline Students-Student's dialogue & 0.635 & 0.557 & 0.386 & 0.394 & 0.562 & 0.855 \\
\hline
\end{tabular}

Table 3. HTMT results

\begin{tabular}{lccccc}
\hline & $\begin{array}{c}\text { Course } \\
\text { structure }\end{array}$ & $\begin{array}{c}\text { Students } \\
\text { Autonomy }\end{array}$ & $\begin{array}{c}\text { Students } \\
\text { background } \\
\text { knowledge }\end{array}$ & $\begin{array}{c}\text { Students prior } \\
\text { experience }\end{array}$ & $\begin{array}{c}\text { Students- } \\
\text { instructor } \\
\text { dialogue }\end{array}$ \\
\hline Course structure & & & & & \\
Students Autonomy & $\mathbf{0 . 8 7 7}$ & & & & \\
Students background knowledge & 0.649 & $\mathbf{0 . 6 8 8}$ & & & \\
Students prior experience & 0.581 & 0.677 & $\mathbf{0 . 7 6 9}$ & & \\
Students- instructor dialogue & 0.779 & 0.720 & 0.596 & $\mathbf{0 . 5 3 5}$ & $\mathbf{0 . 6 2 6}$ \\
Students-Student's dialogue & 0.717 & 0.627 & 0.418 & 0.448 & \\
\hline
\end{tabular}

Note: values in bold represents less $(<0.90)$ root of AVE.

Table 4. Structural model assessment

\begin{tabular}{|c|c|c|c|c|c|c|}
\hline & $\begin{array}{c}\text { Original } \\
\text { Sample (O) }\end{array}$ & $\begin{array}{c}\text { Sample } \\
\text { Mean (M) }\end{array}$ & $\begin{array}{c}\text { Standard } \\
\text { Deviation (STDEV) }\end{array}$ & $\begin{array}{l}\text { T Statistics } \\
(|\mathrm{O} / \mathrm{STDEV}|)\end{array}$ & P Values & Result \\
\hline $\begin{array}{l}\text { Students Autonomy -> Course } \\
\text { structure }\end{array}$ & 0.423 & 0.421 & 0.04 & 10.609 & 0 & Significant $* * *$ \\
\hline $\begin{array}{l}\text { Students background knowledge } \\
->\text { Course structure }\end{array}$ & 0.116 & 0.116 & 0.035 & 3.276 & 0.001 & Significant $* * *$ \\
\hline $\begin{array}{l}\text { Students prior experience -> } \\
\text { Course structure }\end{array}$ & -0.029 & -0.027 & 0.035 & 0.838 & 0.402 & Insignificant \\
\hline $\begin{array}{l}\text { Surdents- instructor dialogue -> } \\
\text { Course structure }\end{array}$ & 0.233 & 0.235 & 0.043 & 5.379 & 0 & Significant*** \\
\hline $\begin{array}{l}\text { Surdents- Surdents dialogue }-> \\
\text { Course structure }\end{array}$ & 0.235 & 0.234 & 0.031 & 7.686 & 0 & Significant*** \\
\hline
\end{tabular}

Note: Not Significant (NS) ${ }^{*} \mathrm{P}>0.05$, Significant (Sig.) ${ }^{* *} \mathrm{P}<0.05,{ }^{* * *} \mathrm{P}<0.01$

\section{Structural Model Assessment}

\section{Path results}

Structural model evaluation (Table 4) was carried out to analyze the path coefficient $(\beta)$ and its significant P.L.S. path modelling levels. We performed the structural model assessment to test the path between the constructs based on the proposed hypotheses. Based on Hair et al. (2016) guideline, we used the bootstrapping technique with 5000 subsamples, a two-tailed test, and a 0.5 significant level to generate the standard error and t-statistics. The overview of the path analysis findings is provided in Table 4 between the five independent variables (Student Autonomy (S.A.), Student background knowledge (S.B.K.), Prior Experience of Students (S.P.E.), Student Teacher Dialogue (S.I.D.), student-student Dialogue (S.S.D.) and the dependent variable (Course Structure). Four of the independent variables are significant and have a positive effect. However, one independent variable has an insignificant effect. As shown in Table 4, Students Autonomy has a significant positive effect on Course structure $(B=0.423)$.

Moreover, the results also highlighted a significant positive effect of Students' background knowledge on Course structure $(\beta=0.035)$. Further, Students- Teacher dialogue and Student-Student dialogue positively 


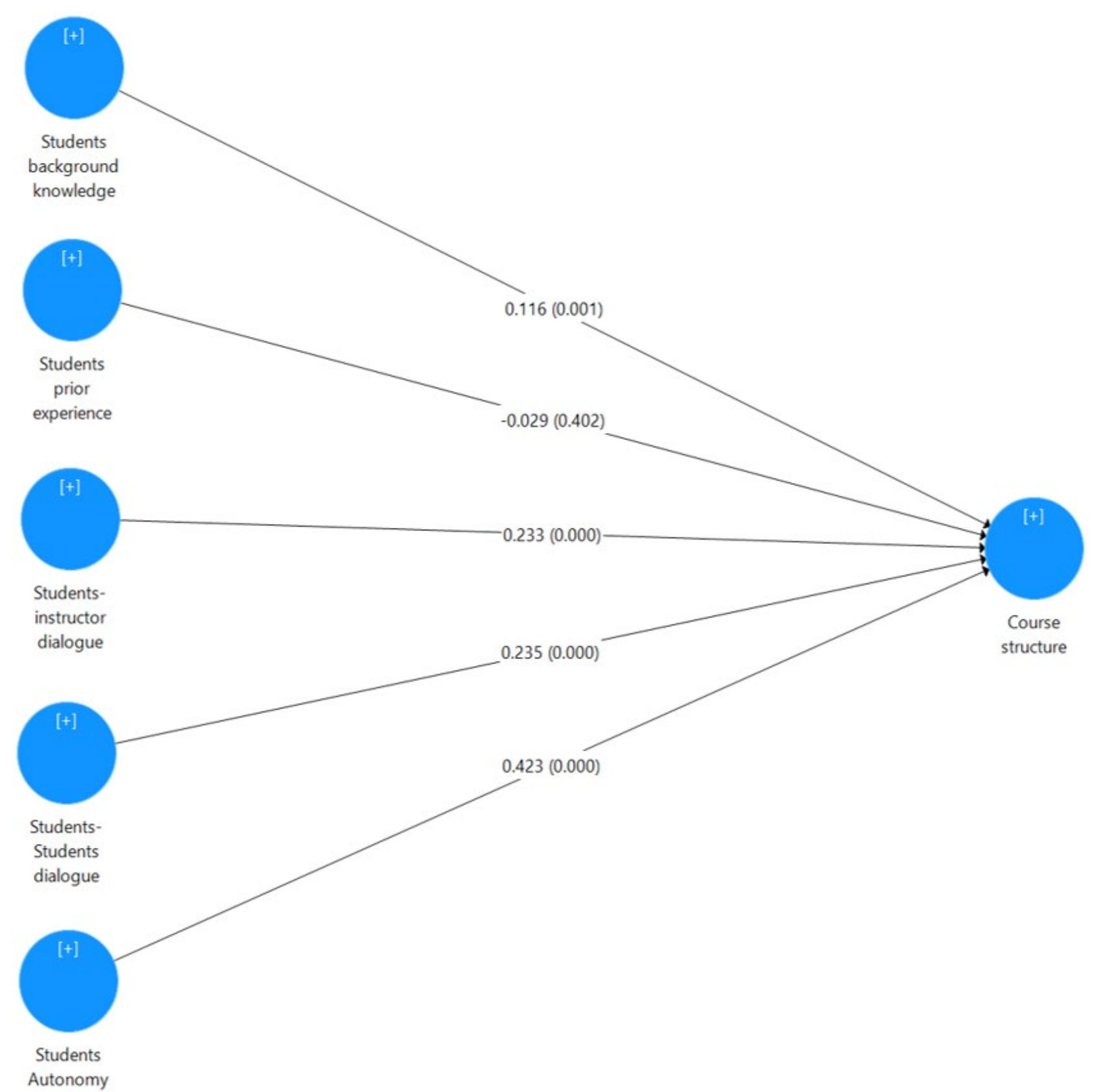

Figure 3. Structural model assessment

affect course structure, and the bootstrapping test showed a highly significant level of both indirect paths with $\beta=0.043$ and $\beta=0.031$, respectively. However, the results revealed that Students' prior experience has an insignificant level with course structure $(\beta=0.035)$.

\section{DISCUSSION}

\section{Student's Background Knowledge}

The current study results highlighted a significant positive effect of Student background knowledge (S.B.K.) on Course structure. These findings are in line with prior research (Abuhassna et al., 2020; Abuhassna \& Yahaya, 2018; Azhari \& Ming, 2015; Ming, 2015; Paechter \& Maier, 2010; Panyajamorn et al., 2018). Students' background factor in online learning environments plays an important role, as suggested in prior studies that there are employment issues in online learning environments, such as learners' readiness, course structure, facilities provided by the educational institute, learners acceptance to online learning, and instructors 
qualification, nevertheless, learners usage of online learning environments are increasing, spreading to global audiences due to its eventual accessibility, flexibility, and exceptional functionality (Azhari \& Ming, 2015). There have been persistent concerns about the quality of online learning environments in comparison with face-to-face environments. Prior studies (Paechter \& Maier, 2010; Panyajamorn et al., 2018) found that students still prefer face-to-face environments due to a lack of background knowledge regarding e-learning interaction reasons and social relations in face-to-face environments. Furthermore, Lau and Shaikh (2012) revealed that Malaysian students' computer skills and internet efficacy, in addition to their demographics like financial income, level of the study, background, and gender, led to a significant variance in their online learning readiness. Furthermore, Abuhassna and Yahaya (2018) claimed that technology in education has made education easier. It plays a crucial role in delivering online learning sessions that as effective as traditional classes despite the psychological separation of instructors and their learners. Online learning environments going through the applications of less complexity in the teaching and learning process, achieving individuals desires that are do not have the opportunity to enrol in face-to-face classes. This study results were comparable to reported results that learners with more background and education level had an advanced readiness level towards e-learning than learners with less education level and background knowledge (Islam et al., 2011; Rasouli et al., 2016). Moreover, this study results believed to be highly relevant to the application of blended learning across various courses as learners with more background and education level had an advanced readiness level towards e-learning than learners with less education level and background knowledge. This conclusion is in line with Salim et al. (2018), who claimed that the implementation of e-learning is limited, and most of the implementations are learners with more background and education level. additionally, students with more knowledge are having a better experience (Farley et al., 2015).

\section{Students Prior Experience}

Students' experience (S.P.E.) regarding online learning environments presents numerous advantages among themselves and their teachers in strengthening their learning experiences, particularly for isolated students. However, more numerous variables are more important when learning via e-learning environments; thus, the results revealed an insignificant effect of Prior Experience of Students on Course structure, which is in contrast with Salmon (2011, 2014), Lau and Shaikh (2012), and Jaques and Salmon (2007). Learners' prior experience in online learning provides numerous advantages to online learners in improving learners' skills, particularly for isolated students (Jaques \& Salmon, 2007; Lau \& Shaikh, 2012; Salmon, 2011, 2014). Nevertheless, of learners' acknowledgment of the benefits of supporting their learning by applying technology in education, complications could occur through their technical abilities restrictions besides prior experiences about employing the software and its functionality. Over the years, it was demonstrated that the lack of feedback and experience in online meetings might often develop a frustration source among instructors and their learners, which may cause uncomplicated tasks, for example, uploading a or submitting an assignment, setting for a quiz or an exam, watching a video, besides other simple responsibilities to be increasingly difficult for them if they do not have the required skills and knowledge and no prior experience. Additionally, when they fill out the assessments, such as presentations online, a relatively limited ability to interact traditionally and rely on a non-verbal signal in conjunction with the audience's body language could be a depressing factor. On the other hand, the significance of being in a situation to take part with classmates in online sessions that are occasionally nonvisual, for example, teleconference set-up is an increasingly important skill in modern sessions, therefore affirming the importance of intensive, clear, concise, communications skills (Salmon, 2011, 2014). Once the study results are assessed in terms of Students' experience towards e-learning it was found to be consistent with prior studies. For instance (Lee et al., 2014), claimed that Students' experience of learning technology is a significant factor for their learning experience. Additionally, a study by Rashid and Asghar (2016) claimed that technology experience possesses a direct positive connection with students' self-directed learning and engagement. Moreover, a study by Eroglu and Ozbek (2018), claimed that the regularity of using the internet in addition to their experience of computers use between students is essential for their attitude about e-learning. Likewise, in accordance with Rhema and Miliszewska (2014), the levels of technology access among students are considered to be a preliminary factor that shapes students' attitudes about e-learning platforms. 


\section{Dialogue}

Purposeful interaction or (Dialogue) in this research defines the communication among learners themselves and learners with their instructors designed to enhance student understanding. Moreover, the results highlighted that both Student-Teacher Dialogue (S.T.D.) and student-student Dialogue (S.S.D.) have a significant positive effect on Course structure; these results are in line with (Abuhassna et al., 2020; Abuhassna \& Yahaya, 2018; Benson \& Samarawickrema, 2009; Furnborough, 2012; Rabinovich, 2009; Shearer, 2010). Dialogue in the present research describes communication, collaboration, and interaction among learners and their instructors and learners to improve learners' understanding and engagement with the course content. Following Shearer (2010) interaction must be constructive in that it is based on the concepts and work from others, such as assisting others in teaching and learning. Moore (1972) declared that students also need to understand the significance of learning communication as an essential part of teaching and learning. Similarly, Benson and Samarawickrema (2009) investigated instructors' preparatory learners, Falloon (2011) examined digital tools' role to help students communicate and interact in a case study conducted in New Zealand. Likewise, Mathieson (2012) studied the dialogue role it plays in online learning sessions; she developed a survey that analyzed learners' perception of audio-visual feedback in classes that use digital tools, such as screen casting. Moore (2007) examines autonomous students looking for factors that do not affect dialogue and structure to improve their learning experience. Furnborough (2012), Abuhassna and Yahaya (2018), and Abuhassna et al. (2020) revealed that learners' cooperation with their classmates impacts their reaction concerning their collaboration with their classmates. Moreover, to examine and refine TDT, Rabinovich (2009) developed a questionnaire to examine TDT in higher education institutions; the questionnaires were sent to 235 learners, who were enrolled in asynchronous web-based graduate session employing TDT and Collaborations, the synchronous learning setting was defined as a place where "live on-campus courses are taken instantaneously to together in-class learners on campus besides remote learners virtually who join through e-learning environments," which permits learners to communicate with both their classmates and their instructor instantaneously (Rabinovich, 2009). Furthermore, Falloon (2011), Kassandrinou et al. (2014), Mathieson (2012), and Vasala and Andreadou (2010) stated that teachers play an essential role as communication and interaction supporters since they are responsible for assisting, reassuring, and encouraging interaction and communication between learners. These results are in line with prior findings (Abuhassna et al., 2020; Major, 2015), which argued that the absence of interactions and delay considerations during asynchronous online courses may have an impact on the learning settings negatively. Additionally, the absence of communications prevents the efficacy in elearning environments.

\section{Student Autonomy}

Students Autonomy (S.A.) considered to be the learner motivation of way toward learning; this current study revealed a significant positive effect of Students Autonomy on Course structure; these results are in line with prior research (Jacobs et al., 2016; Madjar et al., 2013; Massimo, 2014; Stroet et al., 2013). Autonomous learners in this research are referring to their motivation and independence in learning. Students' autonomy in learning exposes their requirements and expectations. Thus, autonomy in online learning environments is of extraordinary importance since the ability to choose is offered in online education, which empowers students in learning autonomy (Massimo, 2014). Moreover, in this regard, the relationship between learners' autonomy and specific parts of the learning process is highly considered. Madjar et al. (2013) has concluded that a learners' autonomy-supportive settings offer these students acceptance of online learning, which leads to more educational accomplishments. This is why autonomy is required in online environments for either learner's development or better accomplishment in university settings. Researchers have also suggested that autonomy strengthens outcomes in aims and goals, guiding instructors' methods primarily to achieve goals.

Consequently, autonomy learning environments have to be designed with affective aspects consideration as well. Nevertheless, Stroet et al. (2013) effectively studied 71 experimental research about the effects of autonomy-supportive education on learner's motivation and found a clear positive association. Students will not reach the same autonomy level without studying students' autonomy insights, reflecting on their educational experiences, sharing these experiences and reflections with their classmates, and understanding 
the factors that influence these procedures (Jacobs et al., 2016). Platforms of online learning additionally are the most suitable ways for autonomous students (Abuhassna \& Yahaya, 2018; Abuhassna et al., 2020; Paechter \& Maier, 2010; Panyajamorn et al., 2018). This study results are in line with a study by ValenciaArias et al. (2019). Their study showed that perception of self-efficacy and learning autonomy are the most important factors influencing e-learning adoption among university students. Similarly, this study results are consistent with prior research (Al-azawei et al., 2017; Tarhini et al., 2017), who claim that e-learning platforms provide learners with better flexibility in their educational experience, accordingly, enhancing their learning experience.

\section{CONCLUSION}

The study shows that e-learning course structure is an effective tool for college learners regarding their autonomy (self-regulated learning), dialogue (whether among themselves or their instructors), and their background knowledge regarding e-learning environments prior experience. Implications for colleges and universities are discussed. Accordingly, such findings provide vital support to the integrative association among collaborative control (CC) and transactional distance theory TDT regarding e-learning environments experience, which might be a great support to universities administrators in the higher education industry to implement, plan, and evaluate online learning platforms applications in their institutes in this outbreak era. This currents research underlines some variables to consider concerning the e-learning course structure. Some variables virtually show that e-learning course structure affects students' overall experience in elearning, and only for those variables e-learning might not be similarly beneficial to others. This research investigated a limited variable. Additional research might be conducted in the future by covering additional variables.

\section{LIMITATIONS OF THE STUDY}

The current research has certain limitations. Firstly, data collected from only 680 students in Malaysian higher education institutions all over Malaysia, which is a small number to be generalized. Moreover, since data collection of this study took place within the COVID-19 pandemic, not all students were encouraged to fill up the google form questionnaire. The current study focuses only on factors that constitute overall e-learning course structure, the relationship among overall e-learning course structure and e-learning student autonomy, background, prior experience, dialogue. There might be other factors that might be considered regarding e-learning course structure. For example, future studies can examine course design considerations, ease to use, student satisfaction, academic achievements, and loyalty towards e-learning environments could be an exciting topic for future research.

\section{RECOMMENDATIONS AND FUTURE WORK}

This study has contributed to the scientific literature by identifying five e-learning course structure factors that must be considered when designing e-learning environments in Malaysian educational institutions. Additionally, the findings reveal a positive relationship amongst overall e-learning course structure and all independent variables of the study, regardless of the student's prior experience. Firstly, based on the finding of the study, the first recommendation would be for administrators of higher institutions. In order to enhance the e-learning course structure, there must be more interest given to the facilities needed. As well as instructor and course developer. Workshops and training sessions must be given for both instructor and student to make them more familiar in order to take the most advantages of e-learning. The software itself is not enough for creating an e-learning environment that is suitable for students and instructors, thus, students' background, students' autonomy, satisfaction, and achievements must be considered in e-learning environments. If instructors were not trained and unaware of utilizing the software in the class, then the quality of education imparted to students will be jeopardized. Finally, Future research could integrate more factors that might enhance e-learning course structure, for instance, learning collaborations, learning communications, and students' readiness towards e-learning environments. 
Author contributions: The corresponding author worked in writing the paper, collecting the data, the second author done all the statistical analysis. Moreover, all authors worked collaboratively to write the literature review and discussion and read and approved the final manuscript.

Funding: The authors received no financial support for the research and/or authorship of this article.

Declaration of interest: Authors declare no competing interest.

Ethical declaration: Ethical approval has been received from University Teknologi Malaysia (UTM) before conduction the data collection. Informed consents are obtained from all participants.

Data availability: Data generated or analysed during this study are available from the authors on request.

\section{REFERENCES}

Abuhassna, H., \& Yahaya, N. (2018). Students' utilization of distance learning through an interventional online module based on Moore transactional distance theory. Eurasia Journal of Mathematics, Science and Technology Education, 14(7), 3043-3052. https://doi.org/10.29333/ejmste/91606

Abuhassna, H., Al-Rahmi, W. M., Yahya, N., Megat Zakaria, M. A. Z., Mohd Kosnin, A. B., \& Darwish, M. (2020). Development of a new model on utilizing online learning platforms to improve students' academic achievements and satisfaction. International Journal of Educational Technology in Higher Education, 17, 38. https://doi.org/10.1186/s41239-020-00216-z

Abuhassna, H., Megat, A., Yahaya, N., Azlina, M., \& Al-rahmi, W. M. (2020). Examining Students' satisfaction and learning autonomy through web-based courses. International Journal of Advanced Trends in Computer Science and Engineering, 1(9), 356-370. https://doi.org/10.30534/ijatcse/2020/53912020

Adams, D., Sumintono, B., Mohamed, A., \& Noor, N. S. M. (2018). E-learning readiness among students of diverse backgrounds in a leading Malaysian higher education institution. Malaysian Journal of Learning and Instruction, 15(2), 227-256. https://doi.org/10.32890/mjli2018.15.2.9

Akaslan, D., \& Law, E. L.-C. (2011). Measuring student E-learning readiness: A case about the subject of Electricity in Higher Education Institutions in Turkey. In H. Leung, E. Popescu, Y. Cao, R. W. H. Lau, \& W. Nejdl (Eds.), ICWL 2011. LNCS (vol. 7048, pp. 209-218). Springer. https://doi.org/10.1007/978-3642-25813-8_22

Al-azawei, A., Parslow, P., \& Lundqvist, K. (2017). Investigating the effect of learning styles in a blended elearning system: An extension of the technology acceptance model (TAM). Australasian Journal of Educational Technology, 33(2), 1-23. https://doi.org/10.14742/ajet.2758

Azhari, F. A., \& Ming, L. C. (2015). Review of e-learning practice at the tertiary education level in Malaysia. Indian Journal of Pharmaceutical Education and Research, 49(4), 248-257. https://doi.org/10.5530/ijper.49.4.2

Barnard, L., Lan, W. Y., To, Y. M, Paton, V. O., \& Lai, S. L. (2009). Measuring self-regulation in online and blended learning environments. The Internet and Higher Education, 12(1), 1-6. https://doi.org/10.1016/j.iheduc.2008.10.005

Benson, R., \& Samarawickrema, G. (2009). Addressing the context of e-learning: Using transactional distance theory to inform design. Distance Education Journal, 30(1), 5-21. https://doi.org/10.1080/01587910902845972

Bolliger, D. U., \& Inan, F. A. (2012). Development and validation of the online student connectedness survey (OSCS). The International Review of Research in Open and Distributed Learning, 13(3), 41-65. https://doi.org/10.19173/irrodl.v13i3.1171

Bradford, P., Porciello, M., Balkon, N., \& Backus, D. (2007). The blackboard learning system: The be all and end all in educational instruction? Journal of Educational Technology Systems, 35(3), 301-314. https://doi.org/10.2190/X137-X73L-5261-5656 
Chawdhry, A., Paullet, K., \& Benjamin, D. (2011). Assessing Blackboard: Improving online instructional delivery. Information Systems Education Journal, 9(4), 20. http://isedj.org/20119/N4/ISEDJv9n4p20.html

Chin, W. W. (2010). How to write up and report PLS analyses. In Handbook of partial least squares (pp. 655690). Springer. https://doi.org/10.1007/978-3-540-32827-8_29

Chopra, G., Madan, P., Jaisingh, P., \& Bhaskar, P. (2019). Effectiveness of E learning portal from students' perspective: A structural equation model (SEM) approach. Interactive Technology and Smart Education, 16(2), 94-116. https ://doi.org/10.1108/ITSE-05-2018-0027

Christensen, R. (2015). Research in schools. In J. M. Spector (Ed.), Encyclopedia of educational technology (pp. 624-627). Sage Publications. https://doi.org/10.4135/9781483346397.n257

Cidral, W. A., Oliveira, T., Di Felice, M., \& Aparicio, M. (2018). E-learning success determinants: Brazilian empirical study. Computer Education, 122, 273-290. https://doi.org/10.1016/j.compedu.2017.12.001

Dewey, E. A. (1972). Understanding children's behaviour. The Counseling Psychologist, 3(2), 120-126. https://doi.org/10.1177/001100007200300217

Eroglu, M., \& Ozbek, R. (2018). The investigation of the relationship between attitudes towards e learning and self-directed learning with technology of secondary school students. International Online Journal of Educational Sciences, 10(5), 297-314. https://doi.org/10.15345/iojes.2018.05.019

Falloon, G. (2011). Exploring the virtual classroom: What students need to know (and teachers should consider). Journal of Online Learning and Teaching, 7(4), 439-451.

Farley, H., Murphy, A., Johnson, C., Carter, B., Lane, M., Midgley, W., Hafeez-Baig, A., Dekeyser, S., \& Koronios, A. (2015). How do students use their mobile devices to support learning? A case study from an Australian Regional University. Journal of Interactive Media in Education, 14(1), 1-13. https://doi.org/10.5334/jime.ar

Fornell, C., \& Larcker, D. F. (1981). Structural equation models with unobservable variables and measurement error: Algebra and statistics. Journal of Marketing Research, 18(3), 382-388. https://doi.org/10.1177/002224378101800313

Furnborough, C. (2012). Making the most of others: Autonomous interdependence in adult beginner distance language learners. Distance Education, 33(1), 99-116. https://doi.org/10.1080/01587919.2012.667962

Gamage, D., Fernando, S., \& Perera, I. (2014). Factors affecting to effective e-Learning: Learners perspective. Scientific Research Journal, 2(5), 42-48.

George, P. P., Papachristou, N., Belisario, J. M., Wang, W., Wark, P. A., Cotic, Z., Rasmussen, K., Sluiter, R., Riboli-Sasco, E., Car, L. T., Musulanov, E. M., Molina, J. A., Heng, B. H., Zhang, Y., Wheeler, E. L., Al Shorbaji, N., Majeed, A., \& Car, J. (2014). Online elearning for undergraduates in health professions: A systematic review of the impact on knowledge, skills, attitudes and satisfaction. Journal of Global Health, 4(1), 1-17. https://doi.org/10.7189/jogh.04.010406

Ghavifekr, S. \& Rosdy, W.A.W. (2015). Teaching and learning with technology: Effectiveness of ICT integration in schools. International Journal of Research in Education and Science, 1(2), 175-191. https://doi.org/10.21890/ijres.23596

Gilbert, J., Morton, S., \& Rowley, J. (2007). E-learning: The student experience. British Journal of Educational Technology, 38(4), 560-573. https://doi.org/10.1111/j.1467-8535.2007.00723.x

Goyal, S. (2012). E-learning: Future of education. Journal of Education and Learning, 6(2), 239-242. https://doi.org/10.11591/edulearn.v6i4.168 
Hair Jr., J. F., Hult, G. T. M., Ringle, C. M., \& Sarstedt, M. (2016). A primer on partial least squares structural equation modeling (PLS-SEM) (2nd Ed.), Sage Publication.

Hair, J. F., Risher, J. J., Sarstedt, M. and Ringle, C. M. (2019). When to use and how to report the results of PLS-SEM. European Business Review, 31(1), 2-24. https://doi.org/10.1108/EBR-11-2018-0203

Hair, J. F., Sarstedt, M., Ringle, C. M., \& Mena, J. A. (2012). An assessment of the use of partial least squares structural equation modeling in marketing research. Journal of the Academy of Marketing Science, 40(3), 414-433. https://doi.org/10.1007/s11747-011-0261-6

Heirdsfield, Walker, S., Tambyah, M., \& Beutel, D. (2011). Blackboard as an online learning environment: What do teacher education students and staff think? Australian Journal of Teacher Education, 36(7), 1-16. https://doi.org/10.14221/ajte.2011v36n7.4

Henseler, J., Ringle, C. M., \& Sarstedt, M. (2015). A new criterion for assessing discriminant validity in variancebased structural equation modelling. Journal of the Academy of Marketing Science, 43(1), 115-135. https://doi.org/10.1007/s11747-014-0403-8

Huang, X., Chandra, A., DePaolo, C. A., \& Simmons, L. L., (2015a). Understanding transactional distance in web-based learning environments: An empirical study. British Journal of Educational Technology, 47(4), 734-747. https://doi.org/10.1111/bjet.12263

Islam, A. M., Chittithaworn, C., Rozali, Z. A., \& Liang, H. (2010). Factors affecting e learning effectiveness in a higher learning institution in Malaysia. Jurnal Pendidikan Malaysia, (Malaysian Journal of Education), $35(2), 51-60$.

Islam, M. A., Abdul Rahim, N. A., Liang, T. C., \& Momtaz, H. (2011). Effect of demographic factors on e-learning effectiveness in a higher learning institution in Malaysia. International Education Studies, 4(1), 112121. https://doi.org/10.5539/ies.v4n1p112

Jacobs, G. M., Renandya, W. A., \& Power, M. (2016). Learner autonomy. In G. Jacobs, W. A. Renandya, \& M. Power (Eds.), Simple, powerful strategies for student centered learning. Springer International Publishing. https://doi.org/10.1007/978-3-319-25712-9_3

Jaques, D., \& Salmon, G. (2007). Learning in groups: A handbook for face-to-face and online environments. Routledge. https://doi.org/10.4324/9780203016459

Jethro, O. O., Grace, M. A., \& Thomas, K. A. (2012). E-learning and its effects on teaching and learning in a global age. International Journal of Academic Research in Business and Social Sciences, 2(1), 203-210.

Johnson, S. D., Aragon, S. R., Shaik, N., \& Palma-Rivas, N. (2000). Comparative analysis of learner satisfaction and learning outcomes in online and face-to-face learning environments. Journal of Interactive Learning Research, 11(1), 29-49.

Jonassen, D., Peck, K., \& Wilson, B. (1999). Learning with technology: a constructivist perspective. Prentice Hall, Inc.

Kassandrinou, A., Angelaki, C., \& Mavroidis, I. (2014). Transactional distance among Open University students. How does it affect the learning Progress? European Journal of Open. Distance and e-Learning, 16(1), 78-93. https://doi.org/10.2478/eurodl-2014-0002

Kaur, N. (2014). Teacher-led initiatives in supporting learner empowerment among Malay tertiary learners. Malaysian Journal of Learning and Instruction, 11, 101-126. https://doi.org/10.32890/mjli.11.2014.7667

Kearsley, G., \& Lynch, W. (1996). Structural issues in distance education. Journal of Education for Business, 71(4), 191-195. https://doi.org/10.1080/08832323.1996.10116783 
Kumar, A. (2017). E-learning and blended learning in orthodontic education. APOS Trends in Orthodontics, 7(4), 188. https://doi.org/10.4103/apos.apos_49_17

Kuo, Y.-F., Wu, C.-M., \& Deng, W.-J. (2009). The relationships among service quality, perceived value, customer satisfaction, and post-purchase intention in mobile value-added services. Computers in Human Behavior, 25(4), 887-896. https://doi.org/10.1016/j.chb.2009.03.003

Language Writing: Developing Self-regulated Learners (2013). Routledge.

Lau, C. Y., \& Shaikh, J. M. (2012). The impacts of personal qualities on online learning readiness at Curtin Sarawak Malaysia (CSM). Educational Research and Reviews, 7(20), 430-444. https://doi.org/10.5897/ERR09.229

Lee, H. J., \& Rha, I. (2009). Influence of structure and interaction on student achievement and satisfaction in web-based distance learning. Educational Technology \& Society, 12(4), 372382.

Lee, K., Tsai, P. S., Chai, C. S., \& Koh, J. H. L. (2014). Students' perceptions of self-directed learning and collaborative learning with and without technology. Journal of Computer Assisted Learning, 30(5), 425437. https://doi.org/10.1111/jcal.12055

Leong, L.-Y., Hew, T.-S., Lee, V.-H., \& Ooi, K.-B. (2015). An SEM-artificial-neural-network analysis of the relationships between SERVPERF, customer satisfaction and loyalty among low-cost and full-service $\begin{array}{llll}\text { airline. Expert Systems with Applications, 6620-6634. } & \text { 42(19), }\end{array}$ https://doi.org/10.1016/j.eswa.2015.04.043

Liaw, S. S. (2008). Investigating students' perceived satisfaction, behavioral intention, and effectiveness of e learning: A case study of the Blackboard system. Computers \& Education, 51(2), 864-873. https://doi.org/10.1016/j.compedu.2007.09.005

Madjar, N., Nave, A., \& Hen, S. (2013). Are teachers' psychological control, autonomy support and autonomy suppression associated with students' goals? Educational Studies, 39(1), 43-55. https://doi.org/10.1080/03055698.2012.667871

Massimo, P. (2014). Multidimensional analysis applied to the quality of the websites: Some empirical evidence from the Italian public sector. Economics and Sociology, 7(4), 128-138. https://doi.org/10.14254/2071-789X.2014/7- 4/9

Mathieson, K. (2012). Exploring student perceptions of audiovisual feedback via screen casting in online courses. American Journal of Distance Education, 26(3), 143-156. https://doi.org/10.1080/08923647.2012.689166

Ministry of higher education (2021). National strategic plan for higher education: Laying the foundation beyond 2020. http://www.ilo.org/dyn/youthpol/en/equest.fileutils.docHandle?p_uploaded_file_id= 477

Moore, M. G. (1972). Learner autonomy: The second dimension of independent learning.

Moore, M. G. (2013). The theory of transactional distance. In M. G. Moore (Ed.), Handbook of distance education (3rd ed., pp. 66-85). Routledge. https://doi.org/10.4324/9780203803738.ch5

Noesgaard, S. S., \& Orngreen, R. (2015). The effectiveness of e-learning: an explorative and integrative review of the definitions, methodologies and factors that promote e-learning effectiveness. The Electronic Journal of e-Learning, 13(4), 278-290.

Paechter, M., \& Maier, B. (2010). Online or face-to-face? Students' experiences and preferences in e-learning. Internet and Higher Education, 13(4), 292-297. https://doi.org/10.1016/j.iheduc.2010.09.004 
Panyajamorn, T., Suthathip, S., Kohda, Y., Chongphaisal, P., \& Supnithi, T. (2018). Effectiveness of E learning design and affecting variables in Thai public schools. Malaysian Journal of Learning and Instruction, 15(1), 1-34.

Pintrich, P. R., Smith, D. A. F., Garcia, T., \& McKeachie, W. J. (1991). A manual for the use of the motivated strategies for learning questionnaire (MSLQ). The University of Michigan.

Raab, T. R., Ellis, W. W., \& Abdon, R. B. (2002). Multisectoral partnerships in e-learning: A potential force for improved human capital development in the Asia Pacific. Internet and Higher Education, 4(3), 217-229. https://doi.org/10.1016/S1096-7516(01)00067-7

Rabinovich, T. (2009). Transactional distance in a synchronous web-extended classroom learning environment (Unpublished doctoral dissertation). Boston University.

Rashid, T., \& Asghar, H. M. (2016). Technology use, self-directed learning, student engagement and academic performance: Examining the interrelations. Computers in Human Behavior, 63, 604-612. https://doi.org/10.1016/j.chb.2016.05.084

Rasouli, A., Rahbania, Z., \& Attaran, M. (2016). Students' readiness for e-learning application in higher education. Malaysian Online Journal of Educational Technology, 4(3), 51-64.

Rhema, A., \& Miliszewska, I. (2014). Analysis of student attitudes towards e-learning: The case of engineering students in Libya. Issues in informing science and information Technology, 11, 169-190. https://doi.org/10.28945/1987

Rosenberg, H., Grad, H. A., \& Matear, D. W. (2003). The effectiveness of computer-aid, self instructional programs in dental education: A systematic review of the literature. Journal of Dental Education, 67(4), 524-532. https://doi.org/10.1002/j.0022-0337.2003.67.5.tb03654.x

Salim, H., Lee, P. Y., Ghazali, S. S., Ching, S. M., Ali, H., Shamsuddin, N. H., Mawardi, M., Kassim, P. S. J., \& Dzulkarnain, D. H. A. (2018). Perceptions toward a pilot project on blended learning in Malaysian family medicine postgraduate training: a qualitative study. BMC Medical Education, 18(1), 206. https://doi.org/10.1186/s12909-018-1315-y

Salmon, G. (2011). E-moderating: The key to teaching and learning online (3rd ed.). Routledge.

Salmon, G. (2014). Learning innovation: A framework for transformation. European Journal of Open, Distance and e-Learning, 17(1), 219-235. https://doi.org/10.2478/eurodl-2014-0031

Salter, M. S., Pharm, B., Karia, A., Sanfilippo, M. F., \& Clifford, M. R. (2014). Effectiveness of e-learning in pharmacy education. American Journal of Pharmaceutical Education 78(4), 112. https://doi.org/10.5688/ajpe78483

Selvaraj, C. (2019). Success of e-learning systems in management education in chennai city-using user's satisfaction approach. The Online Journal of Distance Education and E-learning, 7(2), 124.

Shearer, R. L. (2010). Transactional distance and dialogue: An exploratory study to refine the theoretical construct of dialogue in online learning (Dissertation abstracts), International Section A, 71, 800.

Squillante, J. (2014). Analyzing Blackboard: Using a learning management system from the student perspective (Master's dissertation). http://digitalcommons.lasalle.edu/mathcompcapstones/20/

Stern, D. M., \& Willits, M. D. (2011). Social media killed the LMS: Re-imagining the traditional learning management system in the age of blogs and online social networks. Cutting-edge Technologies in Higher Education, 1, 347-373. https://doi.org/10.1108/S2044-9968(2011)0000001020

Stroet, K., Opdenakker, M. C., \& Minnaert, A. (2013). Effects of need supportive teaching on early adolescents' motivation and engagement: A review of the literature. Educational Research Review, 9, 65-87. https://doi.org/10.1016/j.edurev.2012.11.003 
Strother, J. (2002). An assessment of the effectiveness of e-learning in corporate training programs. International Review of Research in Open and Distance Learning, 3(1), 1-17. https://doi.org/10.19173/irrodl.v3i1.83

Tarhini, A., Hone, K., Liu, X., \& Tarhini, T. (2017). Examining the moderating effect of individual level cultural values on users' acceptance of E-learning in developing countries: A structural equation modelling of an extended technology acceptance model. Interactive Learning Environments, 25(3), 306-328. https://doi.org/10.1080/10494820.2015.1122635

Tseng, L. M., Lin, J. R., \& Chen, P. H. (2011). Evaluating the effectiveness of e-learning system in uncertainty. $\begin{array}{lllll}\text { Industrial Management \& Data Systems, } & \text { 111(6), 869-889. }\end{array}$ https://doi.org/10.1108/02635571111144955

Unwin, T. (2008). Survey of e-learning in Africa. Royal Holloway University of London.

Valencia-Arias, A., Chalela-Naffah, S. \& Bermúdez-Hernández, J. (2019). A proposed model of e-learning tools acceptance among university students in developing countries. Education and Information Technologies, 24, 1057-1071. https://doi.org/10.1007/s10639-018-9815-2

Vasala, P., \& Andreadou, D. (2010). Student's support from tutors and peer students in distance learning. Perceptions of Hellenic Open University “studies in education" postgraduate program graduates. Open Education - The Journal for Open and Distance Education and Educational Technology, 6(1-2), 123-137 (in Greek with English abstract).

Venkatesh, V., Thong, J. Y., \& Xu, X. (2012). Consumer acceptance and use of information technology: Extending the unified theory of acceptance and use of technology. MIS Quarterly, 36(1), 157-178. https://doi.org/10.2307/41410412

Welsh, T. E., Wanberg, R. C., Brown, G. K., \& Simmering, J. M. (2003). E-learning: emerging uses, empirical results and future directions. International Journal of Training and Development, 7(4), 245-258. https://doi.org/10.1046/j.1360-3736.2003.00184.x

White, C. (2003). Language learning in distance education. Cambridge University Press. https://doi.org/10.1017/CBO9780511667312

Wilson, J. W. (2007). The Blackboard jungle: A case study of instructor and student perceptions of the learning technology tool Blackboard (Doctoral dissertation). http://soardev.wichita.edu/bitstream/handle/10057/1184/t07060.pdf?sequence=1

Zhang, D., \& Nunamaker, J. F. (2003). Powering e-Learning in the new millennium: An overview of e-Learning and enabling technology. Information Systems Frontiers, 5(2), 207218. https://doi.org/10.1023/A:1022609809036

Zhang, D., Zhou, L., Briggs, R., \& Nunamaker, J. (2006). Instructional video in e-learning: Assessing the impact of interactive video on learning effectiveness. Information \& Management, 43(1), 15-27. https://doi.org/10.1016/j.im.2005.01.004

Correspondence: Hassan Abuhassna, Faculty of Social Sciences \& Humanities, School of Education, Universiti Teknologi Malaysia, 81310, UTM Skudai, Johor, Malaysia. E-mail: mahassan@utm.my 